University of Massachusetts Amherst

ScholarWorks@UMass Amherst

Masters Theses 1911 - February 2014

1952

\title{
The role of acquired distinctiveness of cues in the acquisition of a motor skill in children.
}

Stanley Lyman Smith

University of Massachusetts Amherst

Follow this and additional works at: https://scholarworks.umass.edu/theses

Smith, Stanley Lyman, "The role of acquired distinctiveness of cues in the acquisition of a motor skill in children." (1952). Masters Theses 1911 - February 2014. 1984.

Retrieved from https://scholarworks.umass.edu/theses/1984

This thesis is brought to you for free and open access by ScholarWorks@UMass Amherst. It has been accepted for inclusion in Masters Theses 1911 - February 2014 by an authorized administrator of ScholarWorks@UMass Amherst. For more information, please contact scholarworks@library.umass.edu. 
THE ROLE OF ACQUIRED DISTINCTIVENESS OF CUES IN THE ACQUISITION OF A MOTOR SKILL IN CHILDREN 
THE POLA OF ACQUIRED DISTITCDIVINESB OF CUEB

IN THE ACQUISITION OF A MOTOH 3NILI IN CEILUREN

\section{by}

Staniey L. Smith

Thes1s Submitted for the Degree of Waster of Science University of Masechusetts

$$
\text { June } 1952
$$


TABLE OF CONTENTS

Page

INTRODUCRION $\ldots \ldots$

Theoretical and Historical Background - . -

Statement of the problen …........

TXPERIMENTAH MEREOD $\ldots \ldots$

Subjects $\ldots \ldots \ldots$

Apparatus and Stimulus aterial … - . -

Procedure $\ldots \ldots \ldots$

RESULTS

Matching of $\mathrm{gs} \ldots \ldots$

Verbal Learning - - . . . . . . . -

Motor Learning - - . - . . . . . -

DISCUSSION $\ldots \ldots \ldots$

Verbal liearning - $-\ldots$

Motor Learning - $-\ldots \ldots$

Hatchine or S - - - . - . - . - -

Verbal Learning Data $\ldots \ldots$ 
INTRODUCTION

\section{Digitized by the Internet Archive in 2014}


There is general agreement amone psychologists and eaum cators that verbal behavior is one of the more important determinants of many manipulative responses. However, there have been very pew detalled theoretical conceptions $(13,14)$ and only a small number of explicit experinental investigations $(2,5,7,15,16,17,18)$ of the relationship between the acquisition of verbal responses and the subsecuent learning of manipulative responses. While of considerable importance for undergtanding the development of motor sirills in yount chilaren, it is interesting thet, with the exception of studies by Birge (2) and pyles (15), relevant explorations have been limited to older chilaren or adults. In the Pormer investigation Birge was concerned with the eifects of prior learning of the same name for alssimilar nonsenge animal stinuli on the extent of positive transfer of a manipulat1ve response. The investigation reported by Pyles and, using a diferent procedure, the present study were concerned with a complementary problem, namely, the deterwination of the relationship between the prior learning of afferent names for different sinilar stinul1 and the subsequent equisition of discriminative notor responses to those same stimuli. 
Theoretical and Historical Background

inller's (12) analysis of the role of verbal responses as antecedents to the occurrence and Iearning of other responses was of greatest sienificance as a theoretical pramework for the present study. In this analysis he proposed that:

"...learning to respond with hichly distinetive names to similar stimulus situations should tend to lessen the generalization of other responses from one of these situations to another since the stimuli produced by responding with the aistinctive narne w11 tena to increase the differences in the stimulus patterns of the two situations. Increased differentiation based on this mechanism has been called acculred distinctiveness of cues." (12, p. 174)

When auplied to motor learning situations, this statement was interpreted as suggesting that learning to make different verbal responses to the component stimuli for manipulative tasks should, by increasing the alstinctiveness of the stinuli, facilitate the acquisition of alfferent monipulative regponses to those discriminada.

Experimental data of relevance por this hypothesis have been reported by several inveatigators. Elghty nursery school, kinderearten, snd first grade pupils served as SS in pyles (15) investigation of the erfects of reming threedimensional nonsense figures on the acquisition of discriminative choice responges to those figures. The same Ss were placed in both naming and no naming condstions in 
counterbalanced order. In the naning conditions both a verbal response and a motor choloe vere acquirec simultaneously, that 1s, woth were evoled on the same triel; a proceare wich precluced spesification of the strength of the verbal reaponse jnapendent of the strength of the motor discrinination. While experience in one treatment resulted in a inared aecrement in triels to oriterion under the other condition, nevertheless, with prior experience equated, nowine the stimuli proved to have significant fac111tative effects on the acquisition of the motor choice reaction.

Rosman and Coss (16), who used college sophonores as Ss, found that learning afferent nonsense syllable responses for the nembers of pars of similar nonsense figures facilitated the subsequent acquisition of aifferent motor responses to merbers of each pair or stimuli. In a related atuoy reported by Gagné and Baker (6) four sroups of young ault go were given $0,8,16$ and 32 triels to learn diferm ent letter labels for each of four ilght-position combinations. Each group was then tralned on a motor task which involved learning to select a alferent switch for each l1ght-position cue, with the result that amount of positive transfer to the motor task was found to increase as a arect function of the number of verba]. learning trials. 
A sensory pre-conditionjing study reported by wakens and Briges (18) indicated that prior experience in alsoriminatırg between a light and tone by means of a verbal response to either the 11 ght or tone stimulus anc no response to the other cue reauced subseouent Eanerazization of $\mathrm{a}$ conditioned response from the light conditionea stinulus to the tore cue.

While the results of these studies tend to corroborate M11.er's enalysis, Thompoon (1.7) found that learning nonsense syliable names for puzzle pictures had no significent facilitative influence on learning to assemble the purale pleces. She suggested, however, that this fallure to obtain a signiflcant difference may have been due to the relative weakness of the verbal responses. Further, her major findIngs, thet rate of learning to asseuble puzzles was difectiy related to the amount of verbalization, offer indrect support for acoured distinctiveness.

An exploratory study conducted by rosg (8) was stimulated by the pact that the possnan and Coss. Gagne and Batrer anc preliminery thompson studies bad not enployed explioit controls for the effects of ss prior haitts of verbalization and warm-up (20). Goss usea three groups, one of which was Elven 60 trials to learn to distinguish among four similar light intensities by means of letter labels. A second ex- 
perimentel group merely esw the stimuld for 60 triala, having been laetructed previously the they were to ind out how the stinul. differed and now wony dfferent one rere presented; the inetructions for this croun were

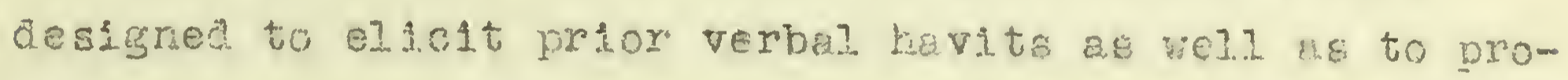
vide an opportunity for warm-up epfects comparable to those for the verbal learning groups. Ss of the thire or control group had no experience with the stimil pror to their introcuction to a motor tesis and reculred the eelection of afferent swithes in response to each of the diferert lisht intensities. During motor learning both the verbal learning and seeinz group made s1enifloantly more correct responses than the control. However, the difference betweer the experimental erougs wa negliglble; a flndug whych Ied. to the conclugion that 60 verbal learndng trialy proviced no sopreciable advantage over the effects of practice in naking previousiy iesmed verbal respones and of werm-up occasioned by seeing and ofscriningting. Subsom quently moro eleborate experimentation hes confirmed the se finaings. In this connection, it will bs recalled that Pyles found that experience in the notor or sinultaneous verbel and motor Aiscriminetion situations had a signifim cant faciltitive effect on porformen in the subsecuent treatment. 
Statement of the problem

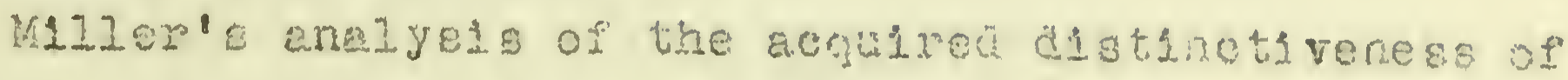
cues leads to the prediction that the acquisition of disw criminetive verbal restonsed shoula, by recuosne interm Etimulue foneralizetion, ocoastor the more repla subgecuent jearning of ajserininative motor restonses to the seme Btializ. Hoveter, consideration of the poseible infuence of warm-up andor or prewexperamentaly aceuired disonimnative vorbal heblts Gnerstes the sare prediotion. where-

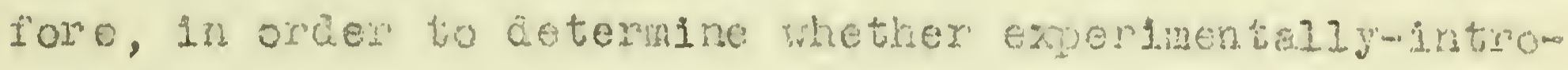

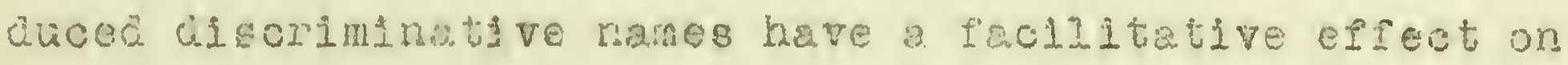

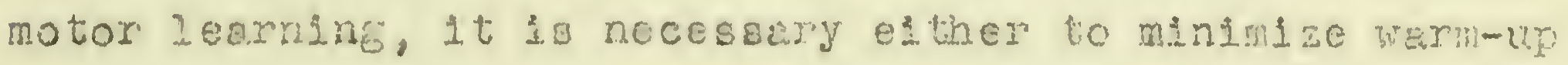
and prior vewal habit factors or to expl101tiy jintroduce those factors to ceo whetrer learning nemes in the experimentri situation he a signifleent aiditionel effect on motor learning.

Becane of relativejy low vosaluiary level, the uge of chlidren as ss seemed to be a posetble means of mininaz1ne the rolo of previously learat verbal habits. Wuthor, since pyled" procedure preciuded independent specifloation

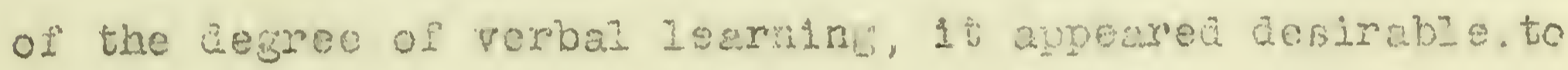
carry out a aludy in whoh degree of verbat learndng coud be more readily manipuiated.

Therapore, utilizing childron as is, and a procedure 
which permitted specification of the amount of prior verbal learning, the presert study was designed to test the hypothesis that pro-learnea verbal alscriminations between airierent areas by means of nonenge syllable names woulú accelerate the rate of acquisition of discriminative motor responses to those same stimull.

While the usa of chilaren probably mininized prior verbal responses there was the possibility that this factor had not been entirely eliminated. Also, there was no reason to believe that the use of children eliminatad or controiled. the warm-up variable. Accordingly, conditions for activating these processes were introjuced explichtily. As a consequence, a more exact, staternent of the hypothesis woulc involve the further stipulation that experimentally introdused names accelerate motor learning over-and-above posaible motor losming facilitation attributgble to warm-up and for previously learned verbal discriminations. 
EXPERIMENTA, METHOD 


\section{Subjects}

The subjects were 48 pre-school and kindergarten chilaren ranging in age from four and one-half to five and onehalf years. These children were obtalned through the cooperation of the Derby Day School in Amherst $(N-8)$, the Bouth Aahorst fins sery and Kindergarten Fchool (1-17), the Mount Holyoke Collegge Nursery School in South Hadley (N-5), the Smith College liursery School and Bay School in Northampton $(\mathbb{N}-13)$ and the Hadey Public school system $(\mathrm{N}-5)$.

In general, the parents of the children would be classified as midäle-midale and upper-midale class, college eaucated, and in sem1-professional, professional, or business occupations. South Hadley, Hadley, and South Amherat are small semi-rural communties of approximately 1000 people each. Amberat has a non-student poculation of 7000 , whlle iorthampton is a small olty of 25,000 .

Chilaren from each school were assigned to all experimental groups and whenever possible were natched on the basis of age and sex. Chilaren for preilminery exploration of experimental procedures were drawn from the ivursery School of the University of Massachusetts. 
Apperatue and stimulus materials

Photographs of the rront and back of the experimental apparatus axe shown in Figure 1. Phis apparatus was designed by the invectigatior; it representa a molification of devices previously employed by Kuenne (12), and Miverts and Enrenfreund (1).

Ferpinont features of tive apparatug are the stimulus aperture in the back penel, the four handes on the horizontal panel and the tube and tray attached to the lower midale eection of the back panel. Sulmul for both verbal and motor learning were exposed in the aperture; between trials the aperture was covered by black cloth curtains.

The four handies on the horizontal panel were used in the motor task. Each handle wats attached to toggle-switches placed in circults whioh, when the switches were closed by S's response, wetivated a llght placea behind the back panel. The se lights served to inform $\mathrm{E}$ which hande had been selected. During experiences prior to rotor learning the handles were detached from the sutches and the response panel wa covered by a plece of nesonite panted flat biack. Wige tube and tray arrangenent, which was within reaching aistance for so, was usea to deliver candy reinforcenent for correct responses.

Each stimulus square was painted on a 13 inch square 

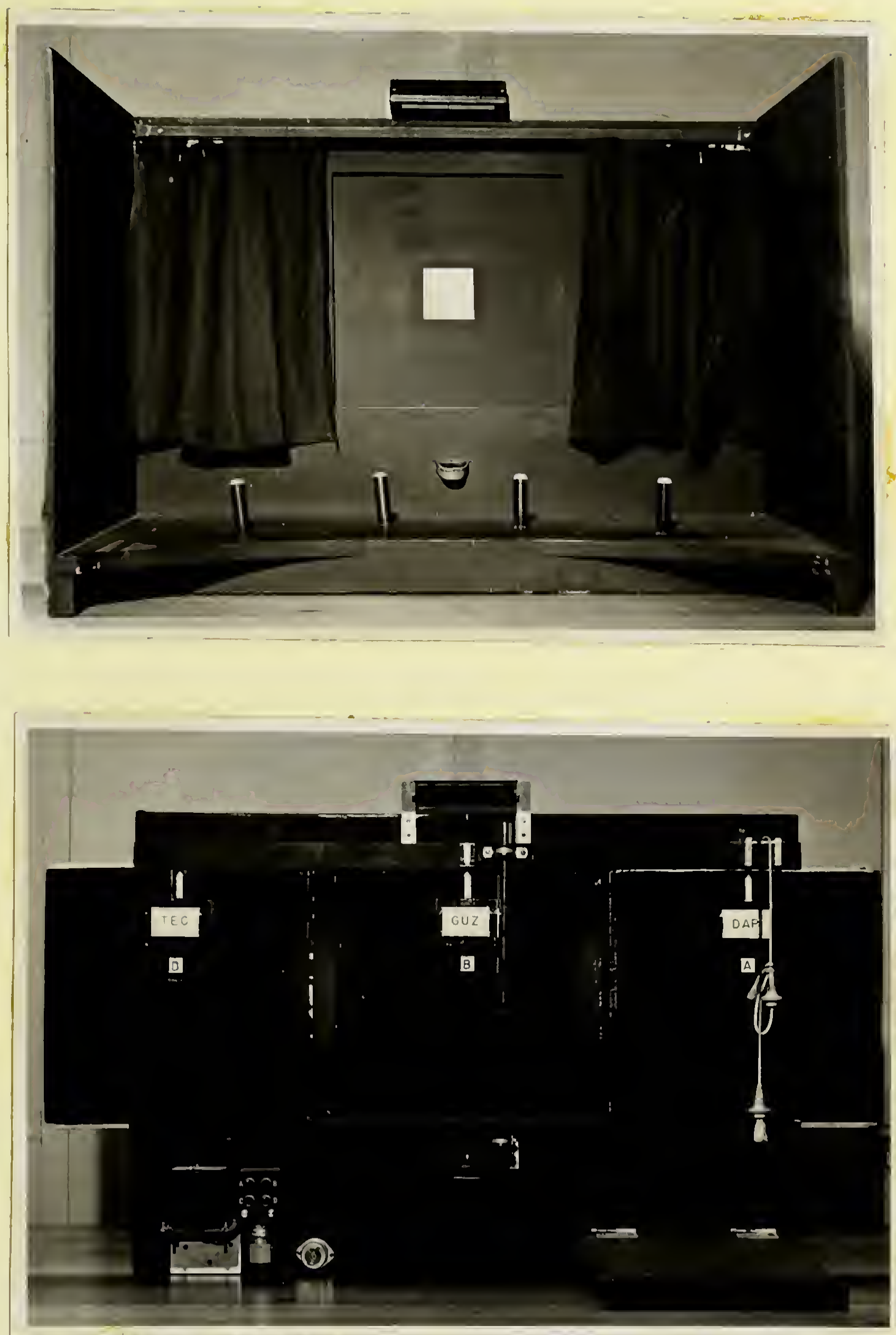

Figure 1.

Front (top) and back (botton) views of the experimental apparatus. 
sheet of heavy tin plate with flat wite; the reat of the sheet ras a llat black. Two cards were placed in each of two pars or paralle top and bottom sloto spaced approximately one-fourth lnoh apart. Before each tral the aporopriate stimulus res pushec into the aperture and at tre termination of that trial was replacea by another atimulus card.

Verbal learning vas by the pelreanssociate nethoj. The stimus for the to-be-learned verbei pesponses were four of Glaze's gyliables of 80 perment associetion value mitch hacl been randomly selected subject to the restriction that the sylablee heve no letters in comnon. The order frintoh the stimil were presented consisted of a random arrancement of the four stimuIi within 25 succesetve blocks, 24 of which consisted of the possible permutatione of the order op four stiruI1. The oriterion for the verbal leamine task was set at seven out of eight correct anticipations in two successive blocks or, ix this was not achieved, the receivea the entire ninety-six verbal learalng trials. Because Ss were of premshool and indergarten ace the syllables were presented oraliy. Also, the two second anticlpation interval usually emoloyed in acult palred-associate learning was extended to five seconds. This interval was controlled by a time delay relay which was activated by opening the 
curtalng at the beginning of each triai.

procecure

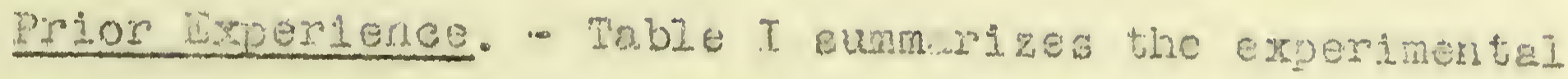

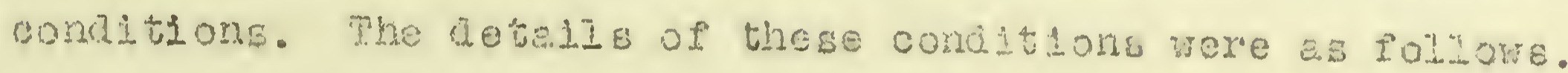

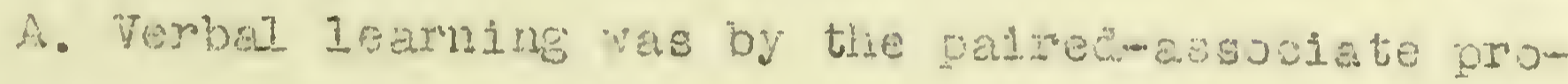
cedure. On each trien. W was shown one of the etimul for five seoung. II, at the end of the pive secord interval,

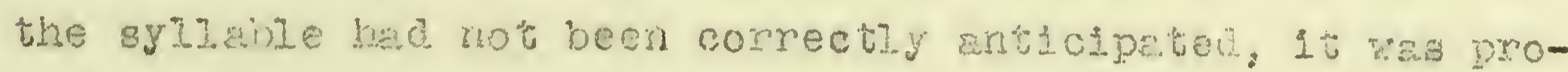

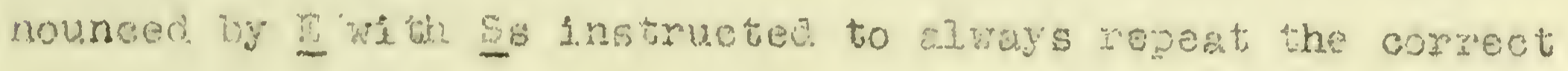

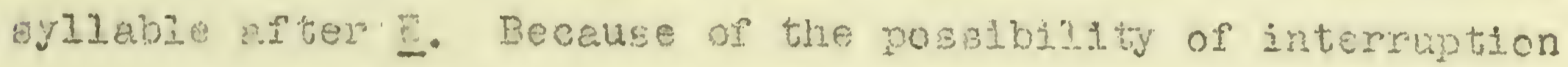

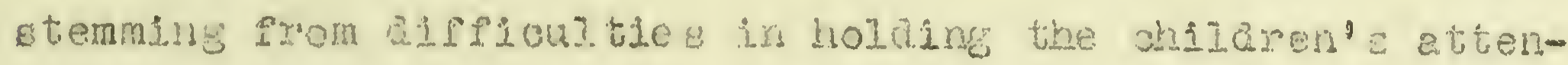
ton no stremgi yas made to hold the inter-brial intorval. constant. These intervale rented froril pive to ten seconds.

Tol'rect 3nticipations wero el weys reinforced by E'G prajoe. Is an aditional reinforcanent component, as well E.3 to occasion wreater resigtruce to extinction $(9)$, siece

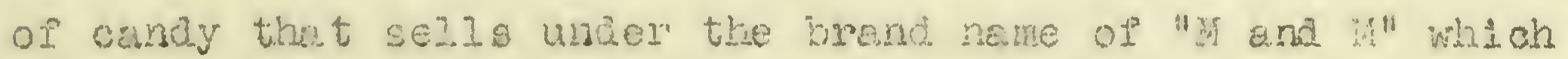
wa aenvered through the tube-and-tang arrangenent, was randomly ahinistered slore with verosi praise on ifty percont of correct anticespepions.

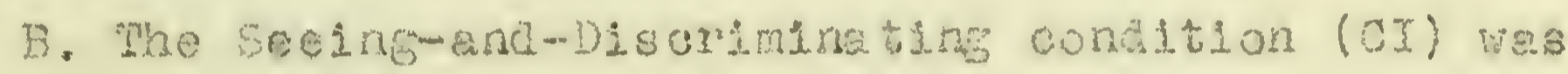
Introducea in order to arouse previously learred verbal noblts as vell as to insure comparable anounts of warm up. Each 3 in this conaition was given the same number of trials, 
but with the axed gtimuli alone, as the metched $\mathrm{g}$ in the verbel Ieaming condition. The se Se vere inetructed to Iook

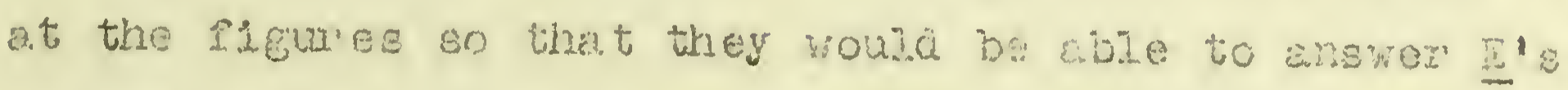
anestione of now were the rigures alferent?" and "yow

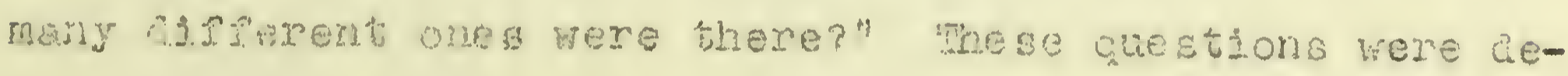
siend to keo then stotendre to the task as weil as to

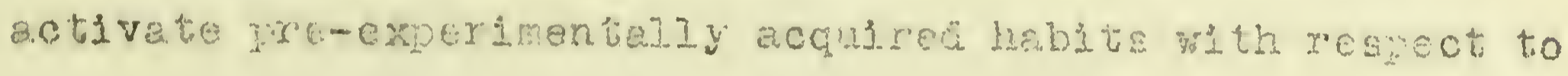
area othimilie aberiniratione.

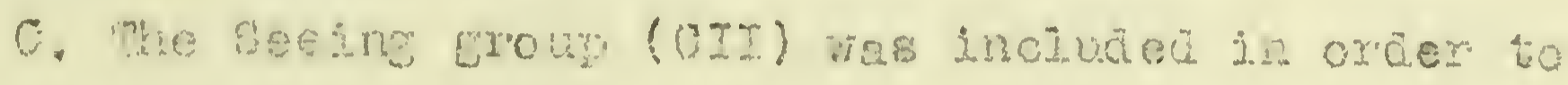

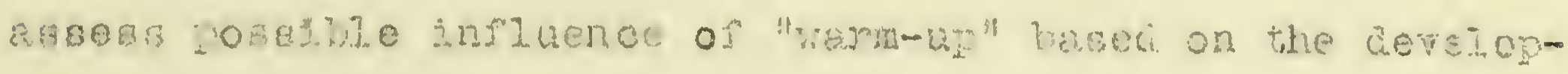
ment of "postural" or "atientive" sets with respect to stimulus ocourrence. To accomitish this, Es in this group were

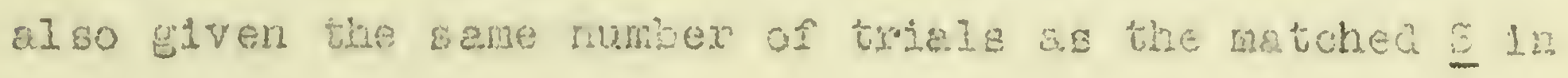
the verbal Iegring group. Duxing these trials each is merely Sav the etimus unjer no speclis ingtructione other than to look at the stimini bu experience wich wat desinned to prepare each sor the stralub presentation sequence of the motor task, hut with a inninum of 210 verbaitzation about the Btimuli. In omer to equate conditions with respeot to lengtin of the the stimuli were seer, on each trial the areas were exjosed to the sis of CI and CII for sipproxinately the same temporal intervel as for the 38 of the experimental grour. Each of these eroups was giver ingtructions appropriate for ltis pre-motor task as pollows: 
TAPLE I.

SUMARAR OF THE EXPERTMENTAL DEBTEN.

\begin{tabular}{|c|c|c|}
\hline Group & $\begin{array}{c}\text { Prior } \\
\text { Experience } \\
\end{array}$ & $\begin{array}{c}\text { Motor } \\
\text { Learning } \\
\end{array}$ \\
\hline Experimental (E) & $\begin{array}{l}\text { Verbal Learning } \\
\text { (96 Trials) }\end{array}$ & 40 Trials \\
\hline Control I (CI) & $\begin{array}{l}\text { Seeing and Discrimi- } \\
\text { nating (96 Trials) }\end{array}$ & 40 Irials \\
\hline Control II (CII) & Seeing (96 Trials) & $40 \operatorname{Tr} 1.218$ \\
\hline Control III (CIII) & None & $40 \operatorname{Tr} 181 \mathrm{~s}$ \\
\hline
\end{tabular}


Terbal learning group

I'm going to show you some figures, one at a time. Each of these figures has a different name. I want you to learn the names of the fleures. When ve start I'Il bhow you the flgure and tell you the name. Then I went to see if you can tell me its name before I tell you, the next time I show you that figure. If you say the wrong name, I'II tell you the richt name; you shoula then say the right name after me. If you say the right name, I'II tell you that you're right and sometimes I'II 1 ive you a piece of candy, the candy w11l come out here.

Seeing and discriminating group

I'r going to show you some rigures, one at a time. I want you to tell ine all about them, what they are. When we are throuch I w111 ask you some questions about the flgures. (If no reaponges are forthcoming after an appropriate number of trials, prod Es with "what do you see, Johnny? )

Viarm-up group

I'r gaing to show you some figures, one at a time. All you have to do is watch them.

D. The subjects of the Control group (CIII) recelved no training with the area stimuli prior to their introduction to the motor task.

Motor Leaming. - The Control erow, and immedately after the completion of the pre-motor experiences, the other groups, were introduced to the motor learning situation by means of the following instructions.

Motor loarning groups

I'm going to show you the (some) flgures (again). This time you're golng to do something different. When I shov you one of the figures. I want you to find out which of these handies goes with the figure you see. What you vill do 1 s pull one of the hanales like this. 
If $1 t^{\prime}$ s the right hande I'Il say "that's right" and (sonetimes) I' 11 give you a plece of candy (the candy w1 come out here). If it 1 on't the right handle. I won't say anything. If I don't sey anything then you may pull another hande and perhavs another unt1I you do rinc the right one. (Sometimes necessary to prod fis on wrong hanales with "try another".)

The instructions required about one ninute. Durlng this time the handles were attached to the togile-situtces. All groups were fiven 40 trials on the motor task which reoulred the selection of one of the four spatially different hanales for each of the four areas. Ss were permittea to correct Incorrect handle cholces until they found the correot handie. Correct hande cholees, that 18 , selections without prior errors, were always rewarded wi verbal pralse. In addition candy rewari was given randomy for fifty perreent of the errorless trials. The stimuli were presented. In 10 four stimulus blocks each of which consisted of a randomiy selected permutation of the order of four events. 
RESUITS 
Matching of EE

Qs withln each school were assigned to each of the experimental conditions; for each achool there was at least one chlld in each condition. When the number of chilaren obtalned for a school was sufficlently large Ss abslgned to the four groups were inatched on the basis of age and sex. Mean ages of chilaren in years and months in the E, CI, CII, and CIII treatments were 5-1, 5-2, 5-1, 5-0 respect1vely. There were sight girls and four boys in the $E$ and CII groups and seven firls and five boy in the two renaining groups. Data for individual $\$ s$ are presented in the Appendix.

\section{Verbal Learning}

Ten of the 12 Ss falled to attain the verbal learning criterion of seven correct responses in two successive blocks of four trials each. During the last twelve and last elght trials these 3 made 48 percent and 46 percent correct responses respectively. The other two Is requirea 20 and 64 trials to reach criterion.

Gibson has postulated that in leaming pairea-associate I1sto which are made up of gimilar stimuli there will be inter-stimulus generalization of responses, that is, each st1mulus w1Il teno to arouse not only its own paired-associate but also the responses to other similar simuli. Further, 
the greater the ginilurity among stimuli the stronger the tendency por each stimulus to eicit the verbal reaponse to similar stimuid. Then the correct resoonses for stimuli are elicited by another etinulug for which the responses axe incorrect those responses are labellea seneralirea responses. Proceeding on the basis op data obtaned in condltioning studies Giogon (7) then hypothesized that, during the course of paired-8sociate learning with simizex intra-tess stimuld, there $1 \mathrm{~g}$ an indigl increage in inter-stimulus generalization, which is followed by a decrease in the frequency of generalized resoonses. In order to abcertain whether the verificatory finding 3 wich she obtained for adult pasred-assoclate learning (7) could also be obteined with children, generalized responges have been plotted (Figure 2) for successive 12-trial blocks of the 96 learning trials for the $103 \mathrm{~s}$ who failed to reach criturion. For the purpose of comparison, the acquisition curve for correct responses for the same Ss has also been plotted. Peralleling Gibson's rindings, the curve for generallaed responses rises to a maximum at the third elghth (trials 25 to 36) and falls off gradually from that point. Had adational learning trials been given it is probeble that the curve would have continued to drop. The learning curve for correct responses appears to be essentially linear. 


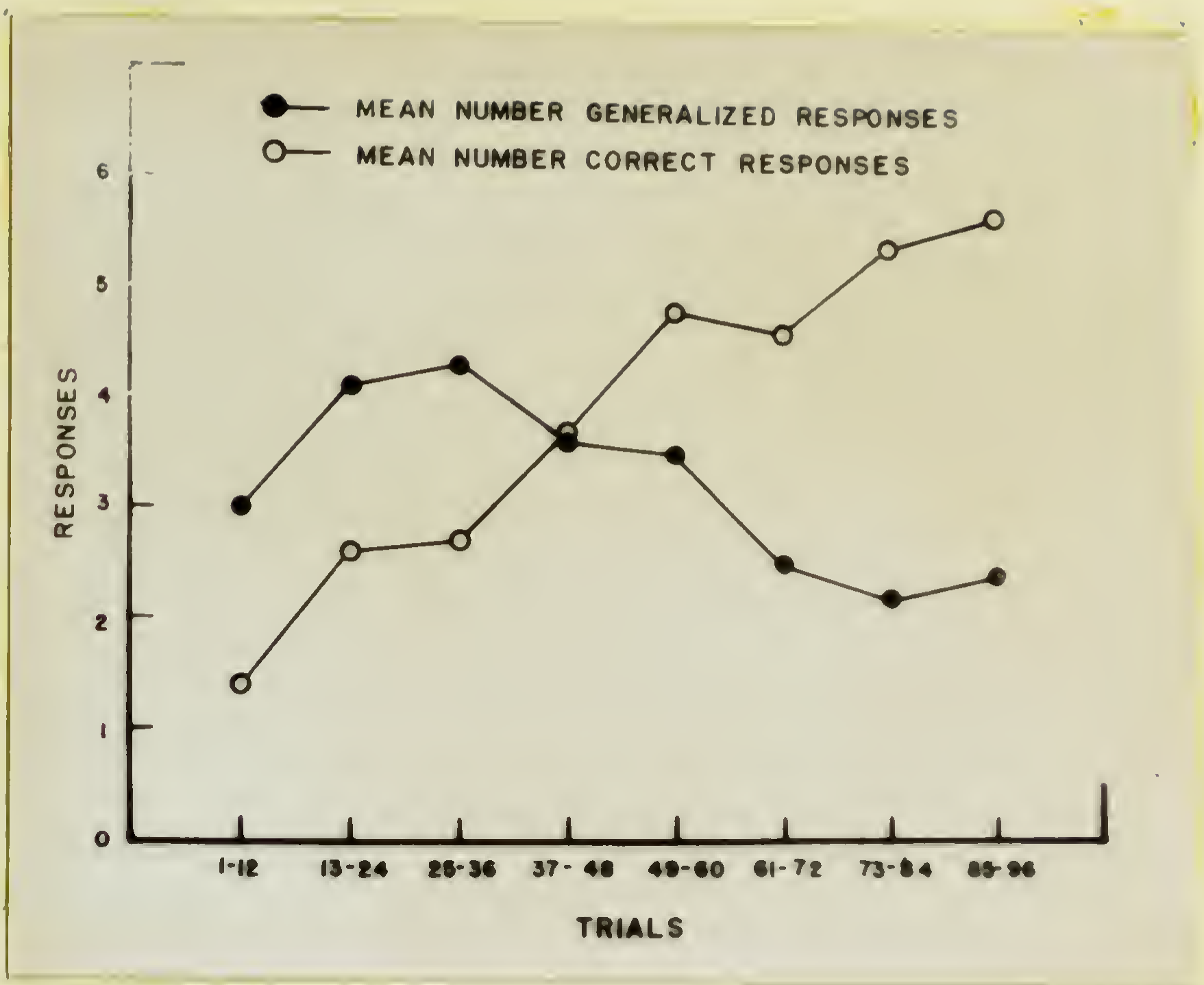

Figure 2.

Means of correot and generalized responses during successive eighths of the verbal learning for loss who were given 90 learning trials. 
Over the corresponalng cortion of triels to criterion, Gibson's Vincentized learning curve was also inear.

It was noted above that the tencency for a siven stimulus to elicit the responses to other stimuli is a decreasing function of the physical. similarity of the stimuli. To cheok this principle, the frequency with which each stimulus evoked the responses to increasingly alssinilar stimuli was determined by the following procedure.

First, those area stimuli successively removed from the smallest square were designated as being $-1,-2$ or -3 steps distant. Similariy those stimuli successively removed from the largest scaure were considered to be at a distance of +1 , +2 , and +3 steps. For the next largest stimulus, the large stimulus was -1 ana the two smaller stimuli were ti and t2 steps removed. The smallest stimulus was calculated to be +1 and the two larger stimuli -1 and -2 steps removed from the next smallest stimulus.

However, stimuli $\pm 3, \pm 2$ and \pm 1 steps removed could occur only once, twice or three times in each block of four trials respectively. Therefore, in order to allow for the unequal possibilities of occurrence of correct and general1zed responses, it was necessary to weight frecuencies of occurrence of the responses to stimuli \pm three steps removed by a multiplyling iactor of four and trose tro steps removed by multiolying by two, while those frequencies for stimuli 


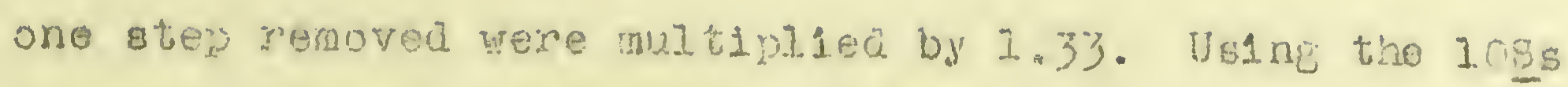
who ald not reach erjterion, Flewe 3 rouresente a not of

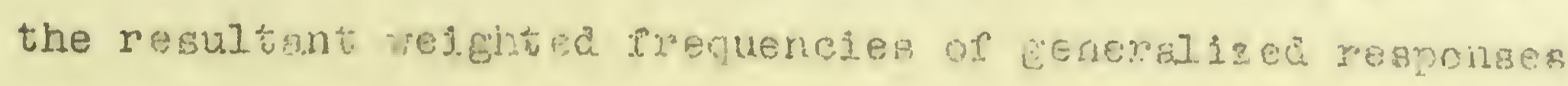
for the prot 12 trlals, the next 36 trals, the last I? trials ani for the entire of trials. While the gradient sor

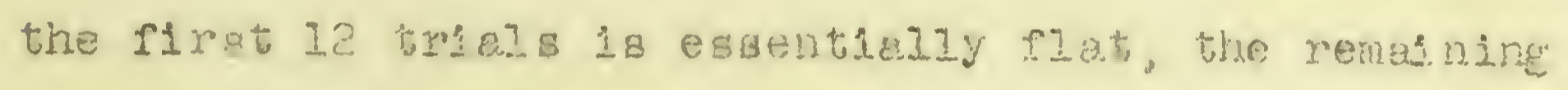
curves apear corsistent, wh the notion strted above, name-

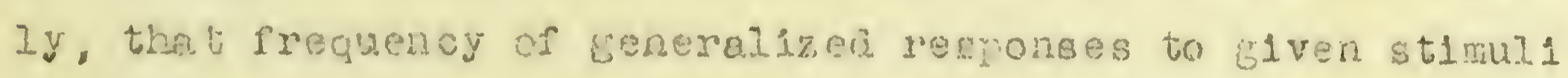
decreases as the Eeneralized pesponses are the correot re-

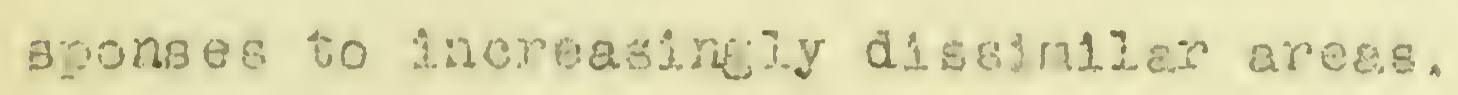

\section{Motor Learrine:}

Motor learnine performance has been analyzed in terms of errorles trials and errors. Means and etandard deviatlons of these measures for the entire 40 trials and for the last 16 trisls have been summarized in Table II. Examination of these data indicate that for both 40 and 16 trials Group $\mathbb{E}$ and $C I$ had more errorless triela ano mede fewer errors than Group,s CII and CIII.

Analysis of varlance (4) was used to test the hypothesis of no differences anong group means for moasures (Tablo III). Analyais of errorless trials moans ylelded 40 and 16 trial F-values of 3.58 and 3.88 respectively, both of which were slonificant at the five percent level of conficience for three and 44 degrees of freedom (ap). For the error 


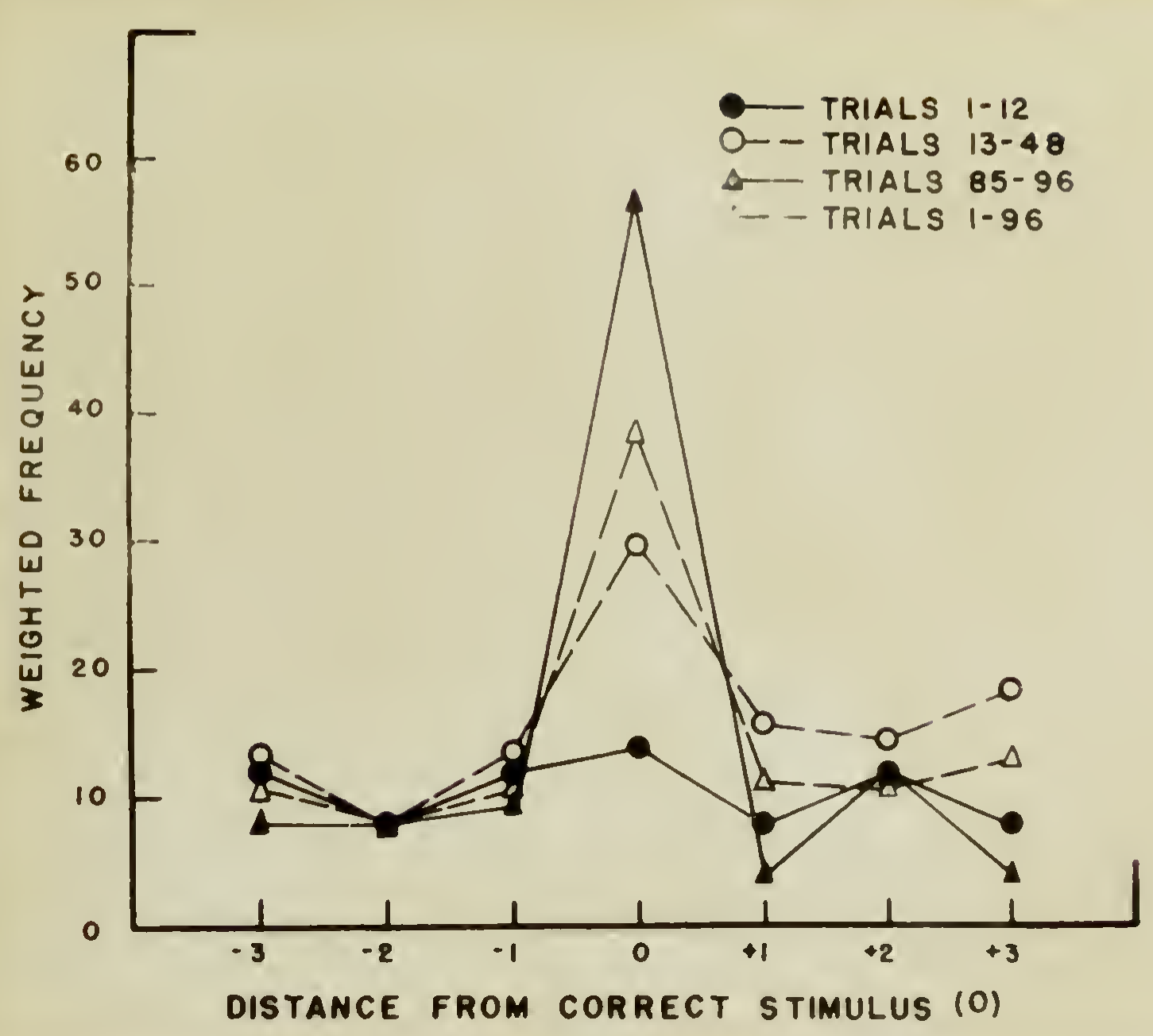

\section{Figure 3.}

Vielghted frequencies of generalized responses for stimull accessively removed from the correct stimulus $(0)$. 


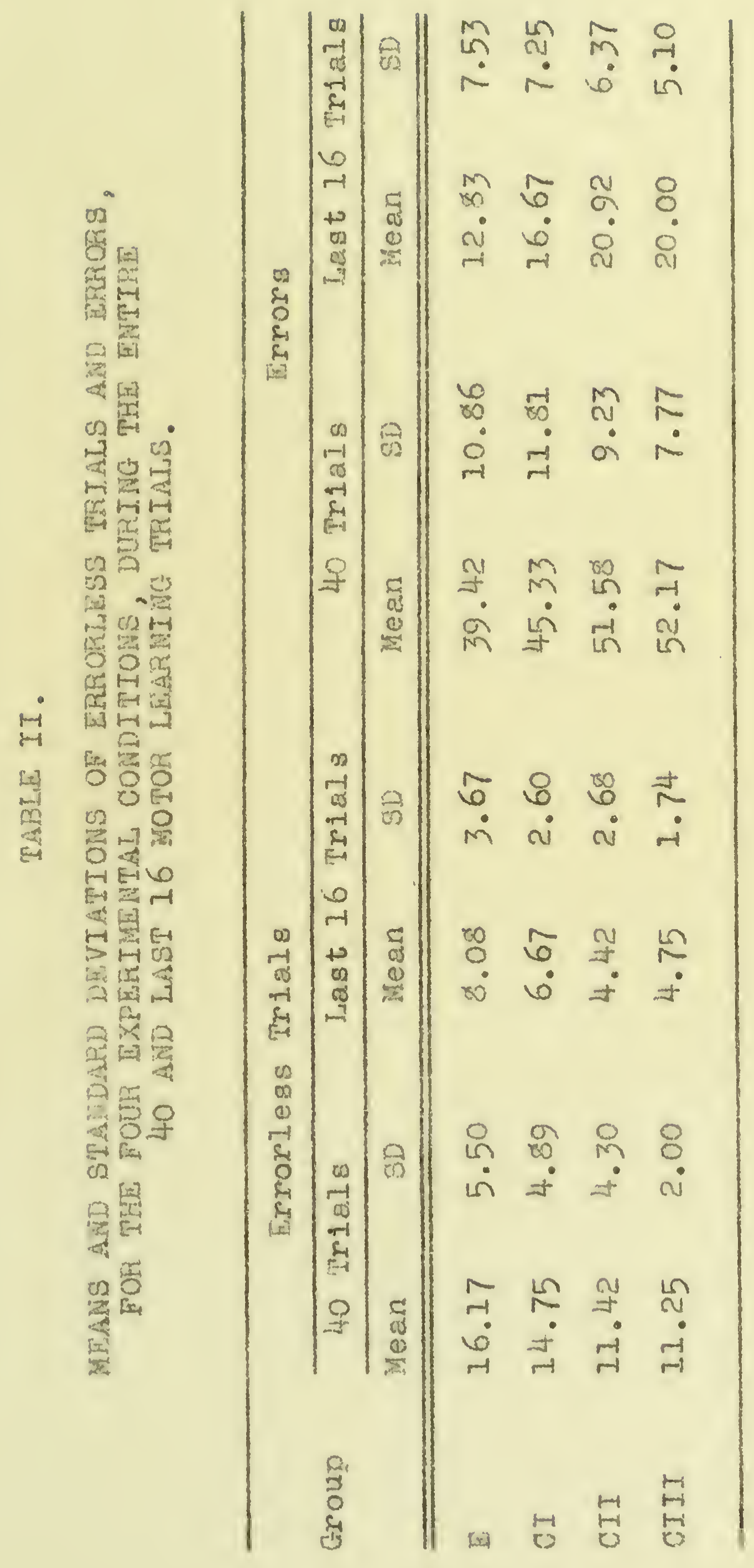




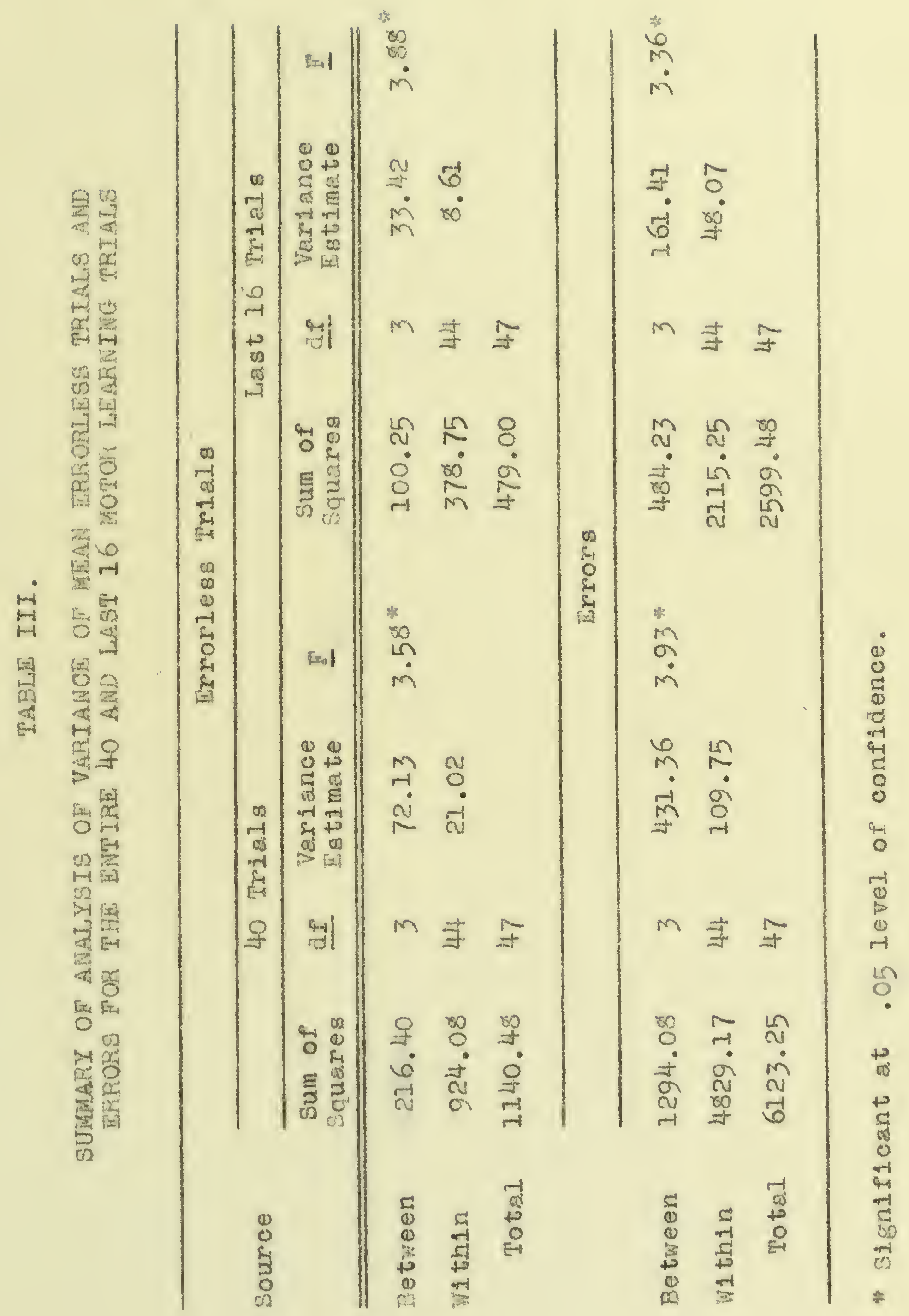


measures, the Fs of 3.36 for total trials sna of 3.93 for the last 16 trials permsted the rejection of the null hypothesis at the one and plve percent levels $(\underline{2}=3,44)$. Thus, statistical analysis suggests that the observed intergroup differences in errorless trials and errors means cannot be attributed to chance factors alone.

In accordance with the experimental hypothesis, whether measured in terms of errorless trials or errors, the motor learning performances of Group E seemed to be sljghtly superior to that of $C I$ and more markedy superior to the perfomances of Groups CII and CIII. However, t-test collparisons of the 40 and 16 errorless trial means for wa CI falled to yleld significant values. 10.75 for 40 trials, $p>.10 ; 1.18$ for 16 trials, $p>.10 .1^{1}$ whlle the $40-t r 1 a 1$ t Por errors was not significant $(\underline{t}=1.36 ; p\rangle .10)$ the $t$ of 1.86 for 16 trials wo. 61 gnificant at the five percent level of confidence. Forty-trid.l mean erroxless trial alfexences for Groups in and CII $(\underline{t}=2.56)$ anci Groups E and CIII ( $\underline{t}=$ 2.62) permitted rejection of the null hypothesis at the one percent level of confidence. For the last 16 trials the

1. Within group varlances from the analysis of variance for exroriess trials and error o were used to compute denominators for the t-test. AII ts are besed on one teil of the t-kistribition and levels of confidence are for 22 degrees of freedon. 
mean errorless trial afferences ylelded te of 3.09 for the Groups $F$ and CII and 2.86 for the Grous E and CII comperisong both of which would heve ocourred only once in 100 times as the result of chance fructuations alone. With respect to mosn errors, total trial ts of 2.84 ( $p<.001$ ) and 2.98 ( $p<.00 J)$ were obtained for groupe FI and CII, sna III and CIII, respectively. Comparison of mesn errors on the last sixteen triale resulted in a $t$ of $3.33(0<.001$ ) for Groupg EI and CII and 3.48 (p <.001) for Groupa II and CIII (Table IV).

While not as large as the differences betweon 40 and 26 trial orrociege trial and error means for Groups E and CII or CIII, correspondine comparisong of Cr and CII OI CIIT. resulted in tg whloh were sienficant at between tho rire and one percent levels of confldence.

Neither of the äifferences between the CJI and CIII. ercorlesa trial or error neang appronched glgnificance. rieures it anc 5 are graphlo representationg of errorless trials wh errors for five succeselpo eleht-trlal units. As indicated by the 40 and 16 trial dats, both E and CI perm formed at a higher level than CII and GII with the letter groups exhio1ting 11ttis or no improvement over the entire 40 trials. Grows 5 and Gr were at aproximetely ocuar values for the rirst 24 tribis. However, the isvergence of 


\section{TABLI IV.}

SUMMARY OF $t$ FOR ALL COMBINATIONS OT MATRS OF YARANS FOR ERRORLWES TRIAIS AND ERRORS FOR THE THTRE 40 AND LAST 16 MOTOR LEARXING TRIALS.

Errors

40 Pre19

E

CI

CII
QI

1.38

$1.86 \%$

CII
CI.

E

II

Last 16 Trials

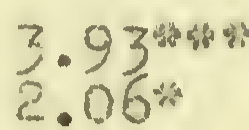

$2.84 \%$ \%क

1.46

CII

GII

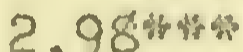

1.60

0.14

Errorless Trials

$40 \operatorname{Iria1s}$

$\begin{array}{llll}E & 0.75 & 2.56 \% & 2.62 \% \\ \text { CI } & & 1.82 \% & 1.87^{*} \\ \text { GI } & & & 0.05\end{array}$

Last $16 \operatorname{Tr} 12.1 \mathrm{~s}$

$\begin{array}{llll}\text { E } & 1.18 & 3.09^{* * *} & 2.86^{*} * 4 \\ \text { CII } & & 1.92^{*} & 2.42^{*} \\ & & & 0.34\end{array}$

* Signifloant at $5 \%$ level.

* SIgnificant at 1 \% level.

** Slgnifleant at $0.1 \%$ level. 


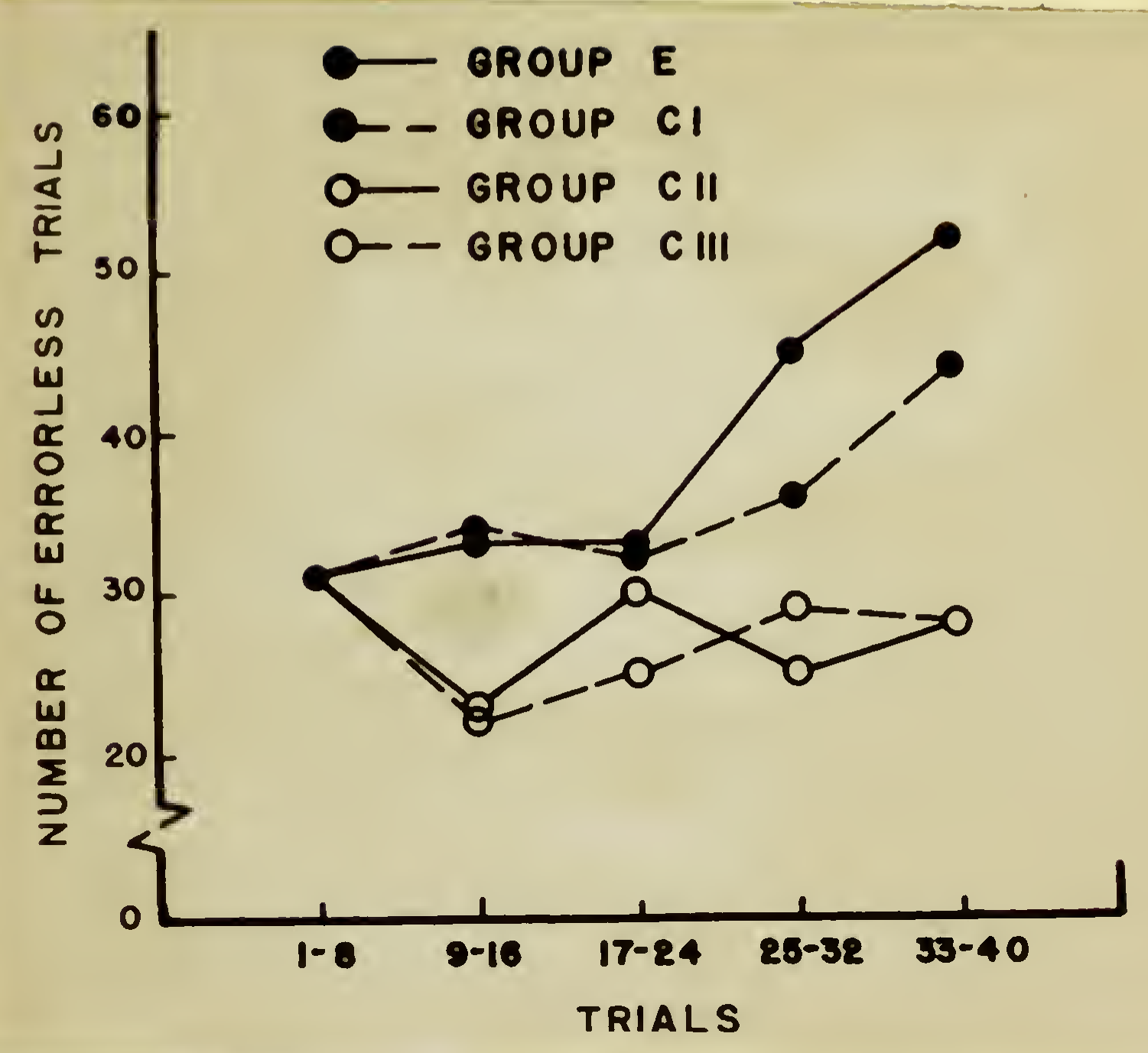

Figure 4.

Total number of errorless motor learning trikis for successive eight-trial blociss. 


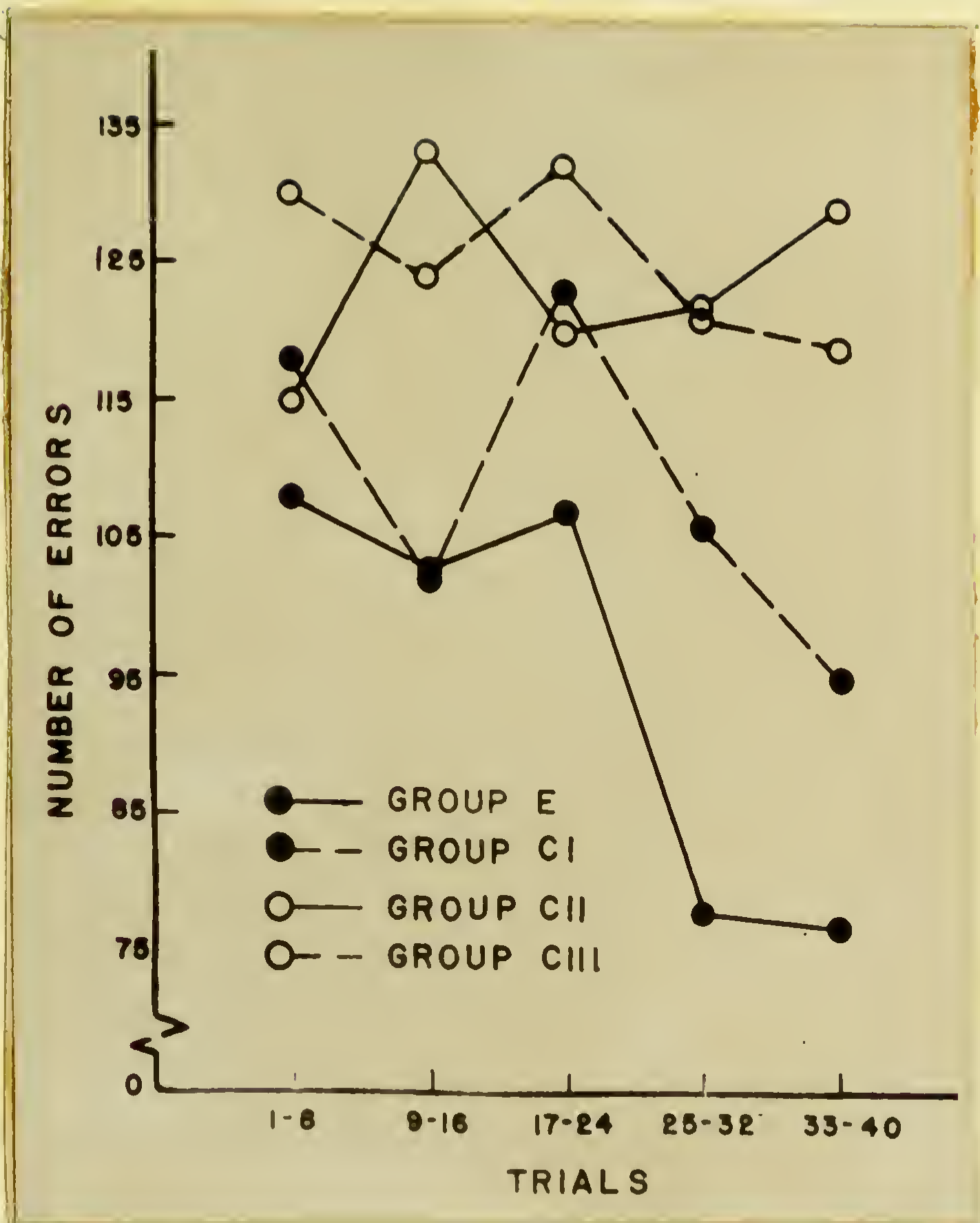

Rigure 5.

Total number of motor learning errorg for successive elght-trial blocks. 
the curves at the last two points sugeeats that had learring been carpled beyond the 50 percent conrect response level,

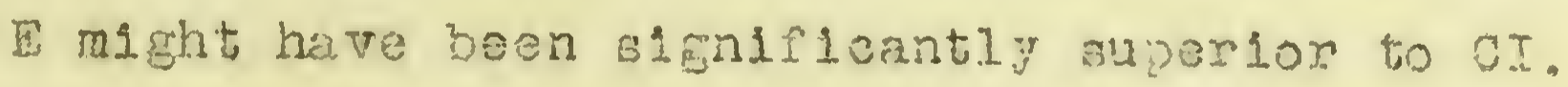

20 conclude, both verbal learning (f) and seenng-andDiocringating (OI) appeared to be signiflcantly more effective premotor le arning experiances than beetng (CII). In fact, Beeins fajled to provide any masurable advantage over no prox experience whatsoever. While the more rand motor learning o: Group $\mathrm{E}$ than of GI vas in the predicted direction, the pallure, with the exception of mean errors for the last 16 trials, to obtaln significant mean differences does not permit the rejection of the possibility that chance factors alone might have aocounted for the ouserved superiority of $\mathrm{E}$.

Uslag the refghting prosedure which was émployed in the analysis of peneralizen verbal responses, inter-stimulus Gonerallzation of notor responses was computed for sach of the four conditions. Pigure 5 represents a plot of the resultant wetghted frequencies of seneralized responsea for the first three elght-trial blocks, the last two eighttrial blocks and for the ent1re 40 trials for the experimental and three control grouns.

It w11. be noted that the most mared generaliation was from the langest to grallest stimulus for Group 

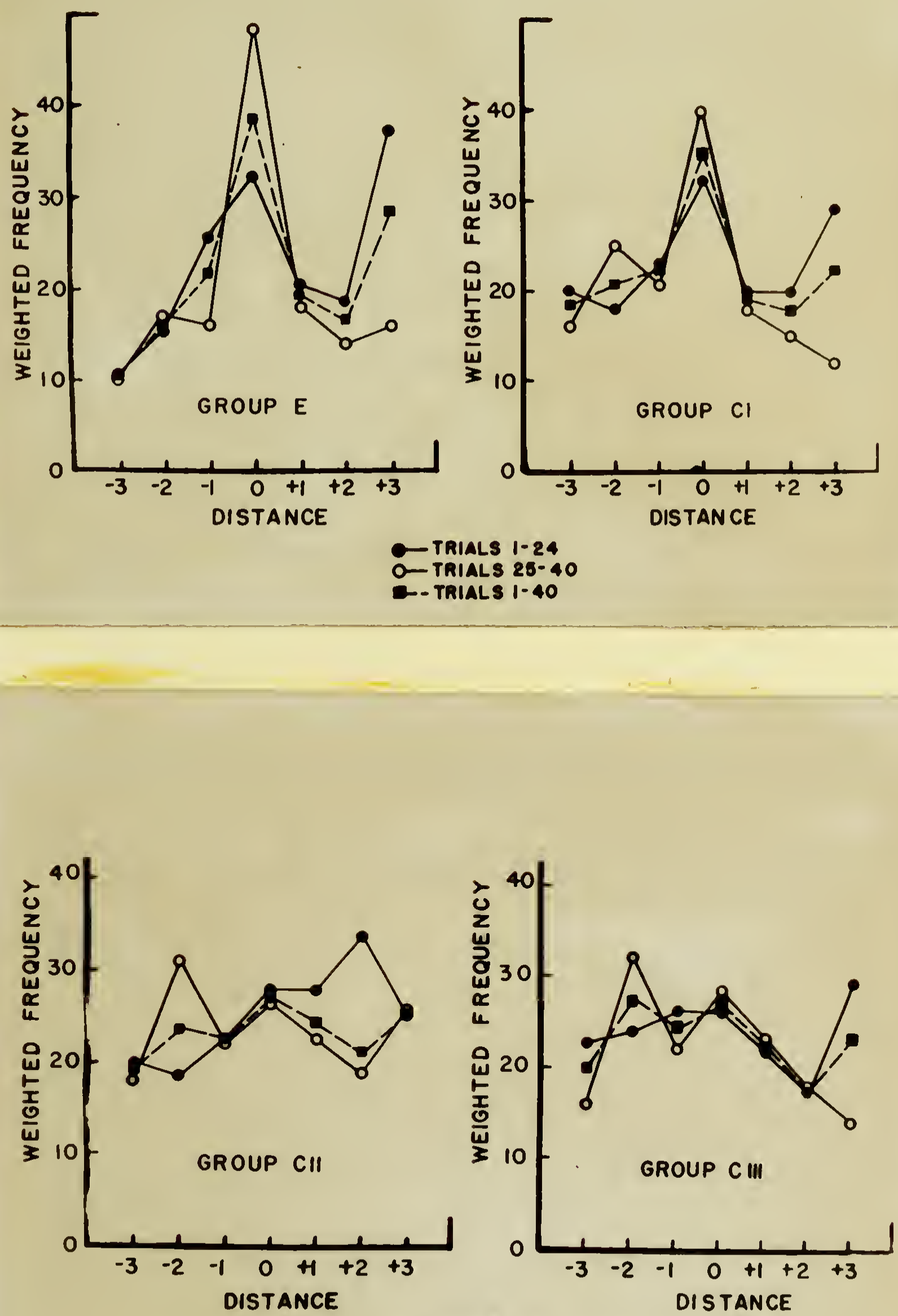

- taials $1-24$

$\begin{array}{ll}\text { O-TRALS } & 25-40 \\ \text { - TRIALS } & 1-40\end{array}$

\section{Fisure b.}

Velghtea frequencles of generalizea resionsea for Groups E, CI, CII, and CIII for stImuII successiveIy removea from the correct stimulus (0). 
Dowever, there was no apparent aiplerence in the frequency Wh th abich the mallest atimulus evolei correct and the Generaldzed reeponse to the iargest stinulus mich was three steps renoved. Apporentiy, periars bocause of verbul re-

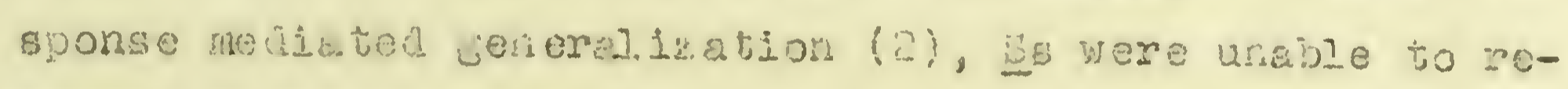
grond. In terng of a distinctio\% between the larester sad the emellest stinulus.

Essentialiy the eane relation whips vere observed tor Group CI. There is no evidence of cenerelizetion por CII arua CII: thus indicating that, over 40 trials, ss in these cond1 thons terdea to make errors equal Iy often to st1mui of varying asinjarity. 
DISCUSSION 
Terbal gennising

Th wea notod provionaly thet during the of yerbal lecrning trials only two of the trelyo 38 meached the established conterson. Thin unexpectecly slon rete or learn

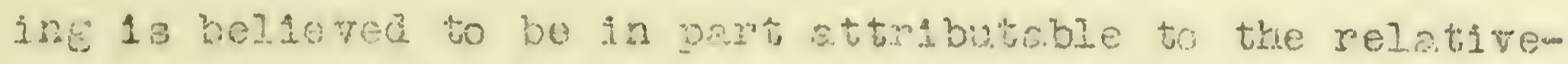
Iy low effectiveress of verbal sccondary reinforcentent for youne children.

To provide a more adequate tsist of the experimonte?

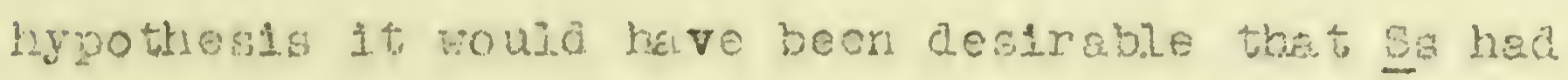
achlever a hicher jovel of verbal iearnthe. Ths objectire might have becin accomplished by admingterang more than 96

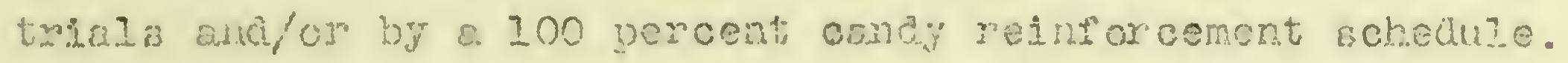
In pianning the experimental procedure the former altornative was ruled cut berouse of the possibility of excessive

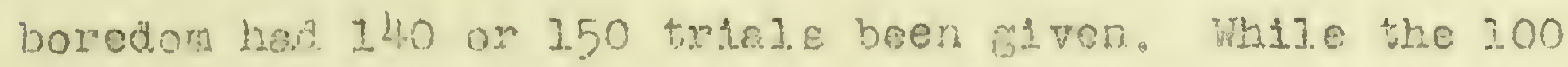
percent procoure might have led to more rond verbal learnins, the nossinllity thet this orocelure might elloo have resulter in more ravgl extanction of the verbal resconses curlne the carly motor leamine trisls led to it r rejection. When generajized responses were nlotted for successive alghth's of the 96 verbal learntag trials, there tab an

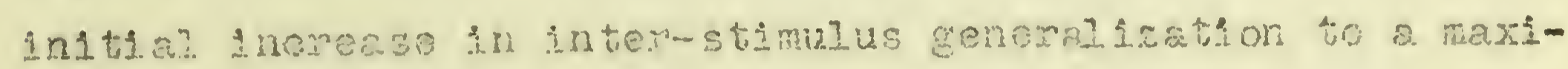
mum at the third cichth, thich wae pollowed by a decrease 


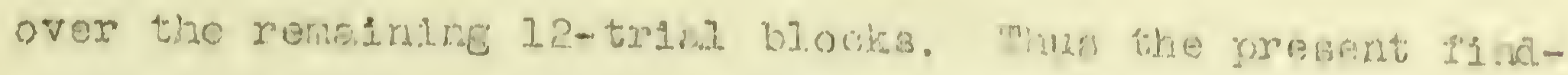

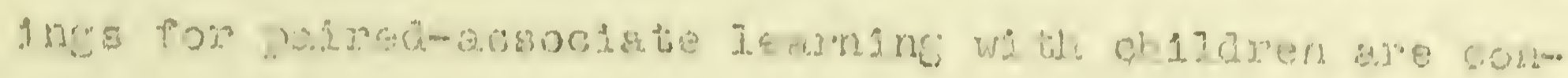

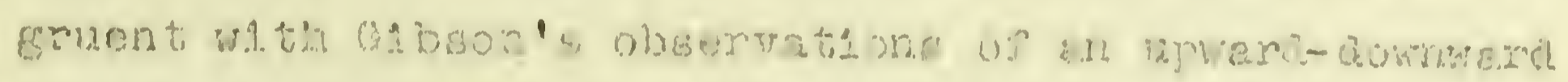

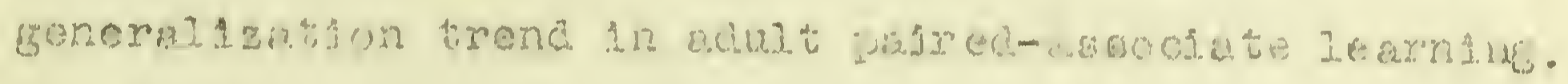

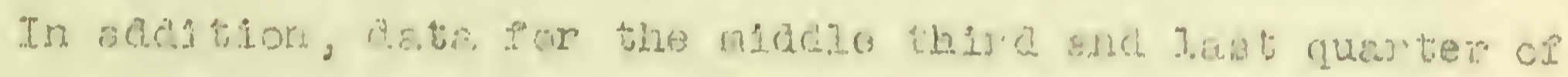

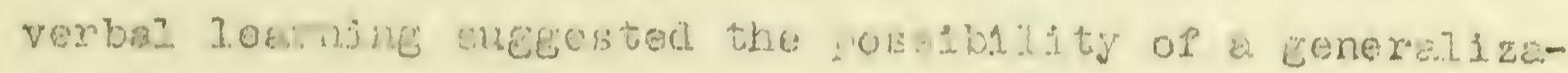

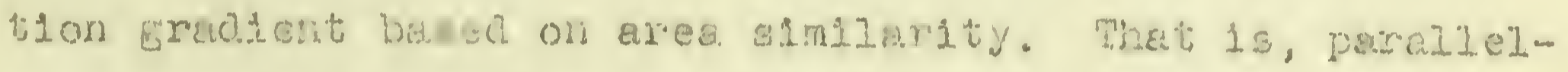

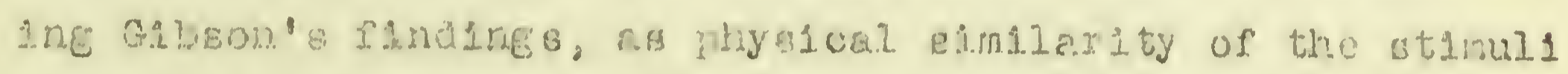

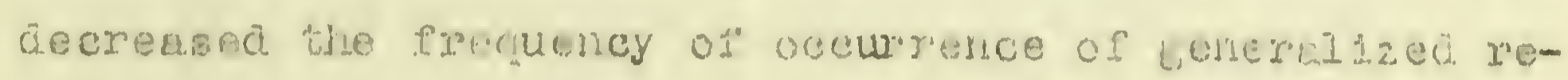
gonnes al a decreasen.

\section{Motor 1 earning}

On the basts of the data collecteo hereln the hypothem

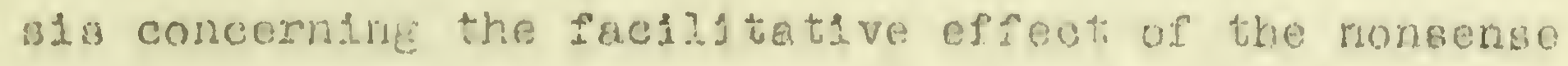

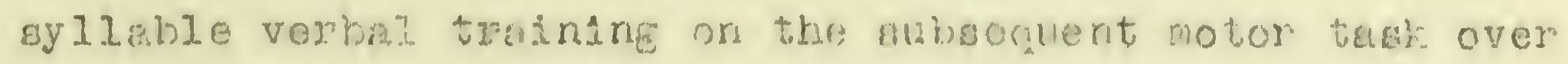

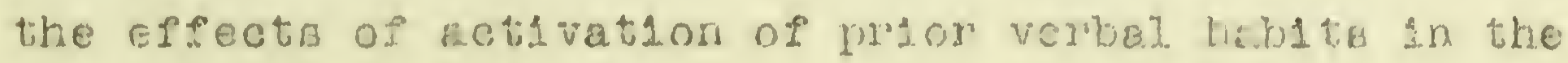
Sec1ne-and-Disoriminating condition has not been substant1eted. However, two considerations incicate the advieability of further experimental explorations of this hypothesis. The first of the conelderations is basol or the alvergence of the errorles triels and error curves for Grolape te ond CI over the last 16 motor learning trials which sugesesto

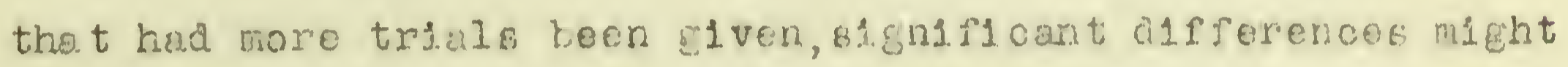
heve been obtanea. Seconaly, the signficent $\underline{t}(1.86)$ for the last 16 trials 18 consistent with the experimental 
hypothesis.

It had been aritcipeted thet both $\mathrm{E}$ and CI would learn more raplaly then CIJ. However, the apperent fallure of the Seeinf treatment to provide a sionificant warm-up efiect over and above no prior experience had not been expectea.

Becsuse of the possibility of continued divergence of verbal leernine and Seeing-and-Discriminating curves it trould appear desirchle thet 60 to so motor learnine trials be employed in subsequent studies. Liso, a 100 percent motor. learning resinoroment schedule would nrobsbly accelerate the ecculsition of correct motor diseriminations.

Txplanation of the fallure for troup to achleve a statistically sienificant superiority over Group CI 1 s based upon the possible influence of elther or both of two fectors. First, it wolld appear possible that the use of 96 verbal learning trials was not sufficlent to bring the Eroup to the degree of mostery necessary for the pregumed fac1l1totive effects of the verbal discrimfinations to occur. Aso, sufficlent forgettine of the verbol responges may have taken place to subetantialiy reduce the inftial arvantace resulto Ing from verbal learning. That forgettin was not complete, however, 1s indicated by the fact that Group E's hypotheE1zed superiority over GI aid not apear unt1l the last 16 trials. 
SUMMA'YX ANI COINLIJSTOWG 
The present sturly was concerned vith an experimental test of M11zer's hypothesis concerning the acoulrou. dsotinctiveness of cues. Specifically, usin children as ss, It was derired to determine whether wrlor exverience with stimul1, which wore to be used in a subsequent motor task, would have e fecilitating effect on the learnin of the motor task. Forty-elght, $41 / 2$ to $51 / 2$ yeer old Nursery School children were alvided into four sroups one of which learned a hidhly dissimilar nonsense sylubio response to each of four white scuares on a bleck ground. A second croup saw the st1mul1 under instructions which were designed to activate previously learned discrimsnatse verbol. reBponses for an equivalont number of trisls. A thira group vas glven wara-up experiences in the iorm of seeing the stimuli for the some number of trials an vere required for verbal leaming. The remalning groun tes introduced to the motor task with no prior expersonce.

Stimull were $124,32,8$ and 2 square inch white scuares on a.black fround. The to-be-1earned motor task consisted of the selection of one of four hanales in regponse to each of the four area stimuil.

Ten of 12Ss falled to reach a criterion of sever of elght correct vorbal responses for two succesalve four - triol 
units und hence vere elven a totaj. of 96 verbal learninfs trials. Analysis of the trend of genorelized restonses confirmed (isbon's hypotherig of an upward-downasd curve of 1nter-binulue eneres.12at1on.

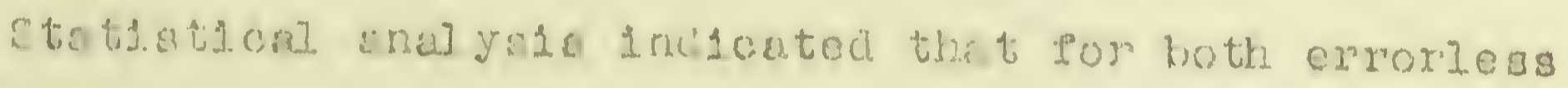
tricle encerrors, the hypothesia of no alfierence among the four froup wotor lounding meang for tho ontire to sna Iest 16 tring could be rejected at the ore jerceut ievel. lowover, whic croup 5 was cupersor to croups CII and CIIT, the predictiod savantabe of $I$ over 01 was not observed. The fellure to flut that verbel leurnine had u giensficant froclititing efrect might have been atiributed to the foct that, at the ond of 96 verbal. loerning, trisis, ss hed reochod \& Ievel of only 50 percent correcti anticipetiong. 
FEFERENCES 
1. Alberts, E. and Ehrenfreund, D., Iransposition in chliaren 2.8 a Iunotion of age. I. exp. Pgychoz., $1951,41,30-35$.

2. BIrge, J, The role of verbal responses in trangfer. Unpublished Ph.D. dissertation, Yale Universt ty, 1944.

3. Dollard, J. and Milier, N. H., Personallty and Psychotherapy. New York: McGraw-4L1 Book Co., Inc., 1950.

4. Eawarid, Allen L., Experimental Desifn In Psycholos 1 cal Pesearch. New York: Rinehart, 1950.

5. Gagne, $\mathrm{R}$. M. and Baker, K. R., Stimuzus pre-different1ation as a factor 1 transfer of training. J. exp. Psychol. , 1950, 40, 439-451.

6. Gibson, E. 3. A systematic application of the concepts of generalization and differentiation to verbal learning. Psychol. Rev., 1940, 47, 196-229.

7. Gibson, E.J., Intru-List Generalization as a factor in verbal training. J. exs. Psychol, 1942, 30, 185, 200.

8. Goss, A. I., Unpublished deta.

9. H1Igard, F. R., Methodis and procedures in the study of learning, in stevens, S. S., (nd.), Handbook of Experdmental Poychology. New Yoris: John viley and Sons, Inc., 1951.

10. Irion, A. L., The relation of "get" to retention. PsychoI. Rev., 1948, 47, 336́-341. 
11. Jenkins, $h$. and tunley, J. C., Partial reinforcement; a remen and emitique. Egychol. Bul1., 1950, 4. $1.93-234$.

12. Kuense, M. R., Gxperimental invertigrtion of the relation of zan uage to transwosition behevion in young chllaren. I. exp. Psychol., 1946, 36, 471-490.

13. M1LIEI, N. E., Theory and experiment reluting psychoarialytic displacement to stiraulus-response generalization. I. abn. Boc. Psychol., 1948, 43, 155-178.

14. M11er, N. E. and Dolkara, J., Sooiaj Iegrning ara InItotion. New Haven: Yale Univeriti Jross, 1941.

15. Pyles, M. K., Verbalization as a sacior in learning. Ch11a Devel.00. , 1932, 3, 10s-113.

16. Rossman, Irna L. and Coss, A. E., Mho acquired distinctiveness of cues: the role of disonininative verbal responses in pecilitatine the acquisition of discrinduative motor reapoizes. J. exo. Psycliol., 1951, $4 \hat{c}, 173-1.82$.

17. Thompson, Toulse, The role of verbalizition in learning from demonatrations. Unpubilished ih.D. Alssertation, Xalo university, 1944.

18. Wokens, D. D. snd Brigerb, E. H. , Hediated stimulus generalization as a sactor in sensory pre-condition-

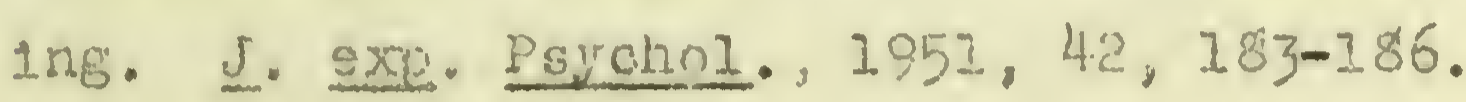


A.PENDIX 
PABT. V.

BUMAYY O SCHOOL, AGE, AND SCX ARTRTUUTES OF ISE TH PACH OF THE EXOSRIMENTA OONDIPIONS.

Name

\section{Experimental Group}

G. Gale

3. Dietel

F. Johrison

J. Hughe

G. Gilardino

J. Fuitor

J. Uexler

J. Levine

$J$. Demotte

S. Neyzon

J. Barstow
Sml th Nursery School

launt HoIyoke jursery sohool

Smith College Day School

Mount, Holyoke Huresery Echool

Smith College Day School

Derby Day School

Derby Day School

South Ankurst Nursery Bchonl South Amherst livesery Bchool South fanherst isurisery Schoo Hadley Kindorgarten

$\begin{array}{ll}4-8 & M \\ 4-9 & \\ 5-2 & M \\ 5-3 & M \\ 5-5 & F \\ 5-6 & 5 \\ 5-0 & 5 \\ 5-0 & 7 \\ 4-10 & 3 \\ 4-73 & 5 \\ 5-4 & 5\end{array}$

Seeing and Disoriminating Group

D. vellg

S. Scott

i. Mason

C. Crone

S. Millara

8. Richards

M. Chapliwy

T. Coririner.am

C. Sheldon

L. W1171ame

E. Rodel

R. Harroj

\section{See1ng Group}

L. Datio

K. Lees

K. Ham12ton

K. Soffer

G. Glanettí

E. Snyder

N. Fusseli

F. Bergluna

C. Bastory

J. Brown

L. Lyons

E. Kosteis

\section{Control Group}

L. Bauer

E. Brownell

J. Decker

P. Ros

J. Hall

S. Laird

P. Hannas

S. Nanstornis

H. Corson

B. Koealier

B. Thompsor

D. Kolosiry
Smith College Nurbery School Derby Day School

Sinth College Jay Sohool

Sist th Coll lege Day School

Wount Holyoke Nursery School Derby Day School

Derby Day School

Mount lolyolse Nursery School South Amherst Nursery Sehool South Anherst Nursery School sualey Kindergarten

faoley kindergerter.

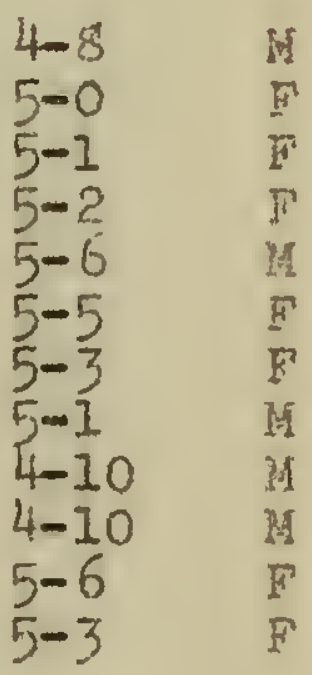

Smlth College Mursery School Smith College Day School

fount Holvoke Nurbery school

Bmith College Day School

Derby Day School

Derby Day School

South Arheret Rurucry school

South Amberst Nursery School

South Amherst Nursery. School

South amberst Nursery chool

South Amherst llursery chool

Hadley Kinderfarten

$\begin{array}{ll}4-7 & F \\ 4-9 & F \\ 4-11 & M \\ 5-5 & F \\ 5-5 & M \\ 5-4 & F \\ 5-3 & F \\ 5-1 & M \\ 4-9 & F \\ 4-6 & M \\ 5-2 & F \\ 5-6 & F\end{array}$

Sinith College Nursery School Smith College Nursery chool Sinth College Day School Smith College Dey School Mount Holyoke Nursery School Derby Day School

South Araherst lluresery School Bouth Amberst Nursery School south ismberst ivurgery sohool South Aruherst ilureery School Souti: Amherst Nursery School Hadley K1ndergarten

$\begin{array}{ll}4-6 & F \\ 4-11 & 5 \\ 5-0 & 5 \\ 5-0 & 13 \\ 5-3 & \\ 5-4 & 5 \\ 5-3 & \\ 5-0 & 5 \\ 4-8 & F \\ 4-6 & F \\ 5-4 & M \\ 5-5 & M\end{array}$


TABLEV VI.

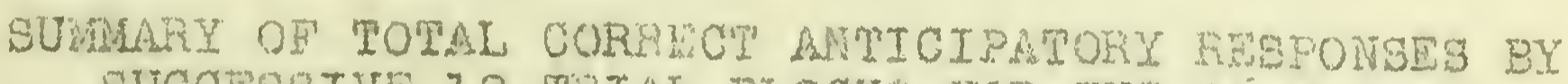
SUCORSSTVE 12-TRIAL BLOCKS WOR WEE 96 VLRBAI

LEARRT NET TRTALS.

\begin{tabular}{|c|c|c|c|c|c|c|c|c|}
\hline \multirow[t]{2}{*}{ Name } & \multicolumn{8}{|c|}{ B10 ckg } \\
\hline & 1 & 2 & 3 & 4 & 5 & 6 & 7 & 8 \\
\hline 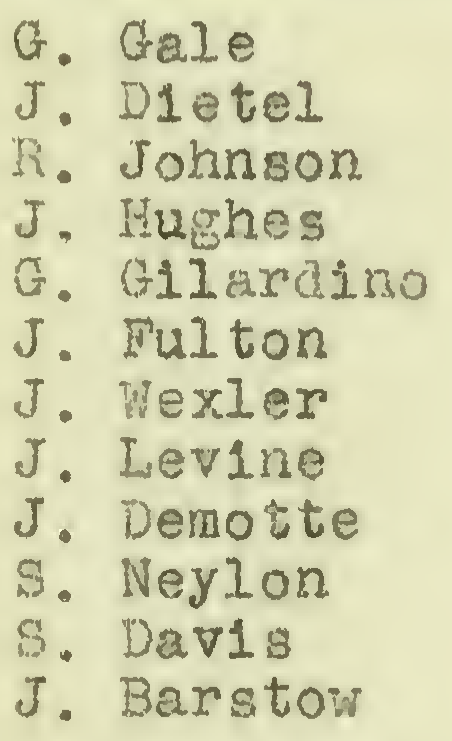 & $\begin{array}{l}1 \\
1 \\
0 \\
4 \\
0 \\
2 \\
6 \\
2 \\
0 \\
3 \\
1 \\
0\end{array}$ & $\begin{array}{l}4 \\
3 \\
4 \\
5 \\
0 \\
3 \\
7 \\
4 \\
2 \\
1 \\
3 \\
0\end{array}$ & $\begin{array}{c}4 \\
3 \\
5 \\
4 \\
5 \\
\cos 1 \\
3 \\
2 \\
3 \\
2 \\
1\end{array}$ & $\begin{array}{l}4 \\
4 \\
8 \\
5 \\
0 \\
8 \\
10 n) \\
1 \\
4 \\
6 \\
3 \\
2\end{array}$ & $\begin{array}{l}6 \\
7 \\
5 \\
8 \\
3 \\
9 \\
4 \\
5 \\
1 \\
5 \\
1\end{array}$ & $\begin{array}{l}5 \\
6 \\
0 \\
6 \\
2 \\
4 \\
3 \\
3 \\
5 \\
1 \\
5 \\
3\end{array}$ & $\begin{array}{c}6 \\
8 \\
9 \\
6 \\
2 \\
\text { cor } 1 \text { ter } \\
4 \\
8 \\
1 \\
5 \\
5\end{array}$ & $\begin{array}{l}4 \\
9 \\
9 \\
6 \\
3 \\
10 n) \\
4 \\
9 \\
2 \\
5 \\
6\end{array}$ \\
\hline
\end{tabular}


TABLE VII

SUMHARY TO TOMAL EFROFLESS TRIALS AND ERROIS BY SUCCESEIVE EIGHI-IRTAI, BLOCKS FOR THE 40 MOTOR LEARWING TRIALS FOR EACH OF THE EXIEFIMENTAL COUDITIONS.

\begin{tabular}{ccc} 
Name & $\begin{array}{c}\text { Errorlese Trials in } \\
\text { Elght-Irial Blocks }\end{array}$ & $\begin{array}{c}\text { Trial Blocks } \\
\text { Tright }\end{array}$ \\
\hline
\end{tabular}

Experimental group

$\begin{array}{lrrrrrrrrrr}\text { G. Gale } & 2 & 2 & 2 & 1 & 2 & 8 & 11 & 9 & 14 & 12 \\ \text { J. Diete1 } & 3 & 4 & 2 & 3 & 6 & 9 & 5 & 10 & 6 & 4 \\ \text { R. Johnson } & 2 & 0 & 2 & 7 & 6 & 11 & 13 & 10 & 2 & 4 \\ \text { J. Hugher } & 4 & 2 & 3 & 6 & 3 & 7 & 7 & 9 & 1 & 7 \\ \text { G. Giliaraino } & 2 & 4 & 2 & 1 & 4 & 10 & 7 & 13 & 10 & 6 \\ \text { J. Fulton } & 4 & 3 & 7 & 7 & 3 & 8 & 7 & 3 & 1 & 0 \\ \text { J. Hexler } & 2 & 4 & 6 & 5 & 4 & 14 & 7 & 11 & 7 & 9 \\ \text { J. Levine } & 0 & 4 & 2 & 3 & 3 & 12 & 11 & 12 & 12 & 5 \\ \text { J. Demotte } & 2 & 1 & 2 & 3 & 5 & 6 & 12 & 11 & 12 & 12 \\ \text { S. Neylon } & 4 & 2 & 2 & 2 & 1 & 9 & 9 & 6 & 4 & 2 \\ \text { S. Davis } & 1 & 3 & 3 & 5 & 7 & 4 & 6 & 11 & 7 & 10 \\ \text { J. Barstow } & 5 & 4 & 1 & 2 & 3 & 10 & 8 & 2 & 2 & 6\end{array}$

Control group I

D. Wells
S. Scott
E. Mason
C. Crone
S. Willard
S. Richards
M. Chapliwy
T. Corkingham
C. Sheldon
L. Williams
D. Rodet
R. Harrop

$\begin{array}{lllll}1 & 1 & 3 & 5 & 4 \\ 4 & 2 & 1 & 1 & 3 \\ 4 & 2 & 1 & 3 & 5 \\ 2 & 2 & 1 & 3 & 4 \\ 4 & 4 & 2 & 3 & 4 \\ 1 & 3 & 1 & 1 & 2 \\ 1 & 2 & 3 & 1 & 3 \\ 2 & 4 & 0 & 3 & 2 \\ 1 & 2 & 5 & 4 & 5 \\ 4 & 3 & 4 & 2 & 1 \\ 4 & 5 & 6 & 5 & 5 \\ 3 & 4 & 5 & 5 & 6\end{array}$

$\begin{array}{rrrrr}14 & 13 & 7 & 4 & 6 \\ 7 & 7 & 17 & 14 & 13 \\ 4 & 10 & 12 & 9 & 6 \\ 10 & 12 & 14 & 7 & 9 \\ 7 & 7 & 9 & 6 & 7 \\ 13 & 5 & 17 & 15 & 12 \\ 16 & 7 & 14 & 14 & 10 \\ 10 & 6 & 13 & 8 & 10 \\ 13 & 12 & 7 & 6 & 4 \\ 8 & 10 & 6 & 13 & 13 \\ 8 & 6 & 2 & 4 & 3 \\ 8 & 7 & 5 & 6 & 2\end{array}$

Control group II
L. Dav13
K. Lees
K. Hamiltion

$$
\begin{array}{lllll}
3 & 3 & 1 & 1 & 2 \\
2 & 2 & 4 & 3 & 2 \\
4 & 1 & 4 & 0 & 1 \\
0 & 1 & 1 & 1 & 2 \\
3 & 4 & 3 & 1 & 1 \\
3 & 1 & 1 & 3 & 1 \\
1 & 3 & 2 & 1 & 2 \\
4 & 2 & 1 & 3 & 1 \\
4 & 1 & 5 & 6 & 6 \\
2 & 3 & 5 & 2 & 4 \\
4 & 1 & 2 & 1 & 1 \\
1 & 1 & 1 & 3 & 2
\end{array}
$$

$\begin{array}{rrrrr}5 & 9 & 12 & 9 & 4 \\ 9 & 11 & 12 & 2 & 9 \\ 12 & 15 & 11 & 14 & 10 \\ 10 & 10 & 13 & 10 & 12 \\ 5 & 7 & 10 & 14 & 15 \\ 11 & 9 & 9 & 11 & 13 \\ 7 & 8 & 10 & 7 & 7 \\ 11 & 12 & 10 & 11 & 14 \\ 10 & 10 & 12 & 13 & 5 \\ 10 & 8 & 12 & 8 & 12 \\ 15 & 12 & 10 & 11 & 9 \\ 15 & 13 & 11 & 11 & 9\end{array}$

Control group III

$\begin{array}{lrrrrrrrrrr}\text { L. Bauer } & 4 & 0 & 2 & 6 & 2 & 9 & 10 & 12 & 14 & 13 \\ \text { E. BrownelI } & 3 & 1 & 3 & 2 & 1 & 12 & 7 & 8 & 5 & 9 \\ \text { J. Decker } & 3 & 2 & 1 & 2 & 1 & 7 & 13 & 6 & 13 & 17 \\ \text { P. Ross } & 1 & 3 & 2 & 1 & 1 & 17 & 13 & 15 & 13 & 9 \\ \text { J. Hall } & 2 & 3 & 3 & 2 & 1 & 8 & 6 & 7 & 11 & 8 \\ \text { S. Laira } & 3 & 1 & 2 & 3 & 4 & 9 & 12 & 12 & 6 & 12 \\ \text { P. Hannus } & 2 & 1 & 2 & 2 & 1 & 9 & 10 & 12 & 11 & 14 \\ \text { S. Nanatornis } & 3 & 1 & 2 & 2 & 5 & 5 & 10 & 16 & 9 & 12 \\ \text { M. Coplon } & 3 & 3 & 2 & 3 & 2 & 8 & 13 & 6 & 4 & 2 \\ \text { B. Koesta } & 1 & 3 & 2 & 2 & 3 & 11 & 10 & 8 & 10 & 9 \\ \text { B. Thompson } & 2 & 2 & 3 & 2 & 3 & 6 & 15 & 9 & 16 & 13 \\ \text { D. Kolosky } & 4 & 2 & 1 & 2 & 4 & 14 & 14 & 9 & 10 & 11\end{array}$




\section{ACKNOWIEDANENT}

Graterul acknowledgment is expresseo. to propessor Albert Goss for his guldance and untiring effortg in the capacity of Departmental Adv1sor. Appreciation 1s also expressed to Mrs. Em1ly Thies, Oirector of the University of Massachusetts Nursery School; and to the other partlelpating Schools for their full cooperation in the selection of the subjects. Grateful recognition is also expressed to Mr. Joseph Mach for his ald in the construction of the apparatus. Lastly, recognition 18 given to my wife, who by her pereeverence and understandinf, is in part responsible for the present paper. 
APPROVED BY:
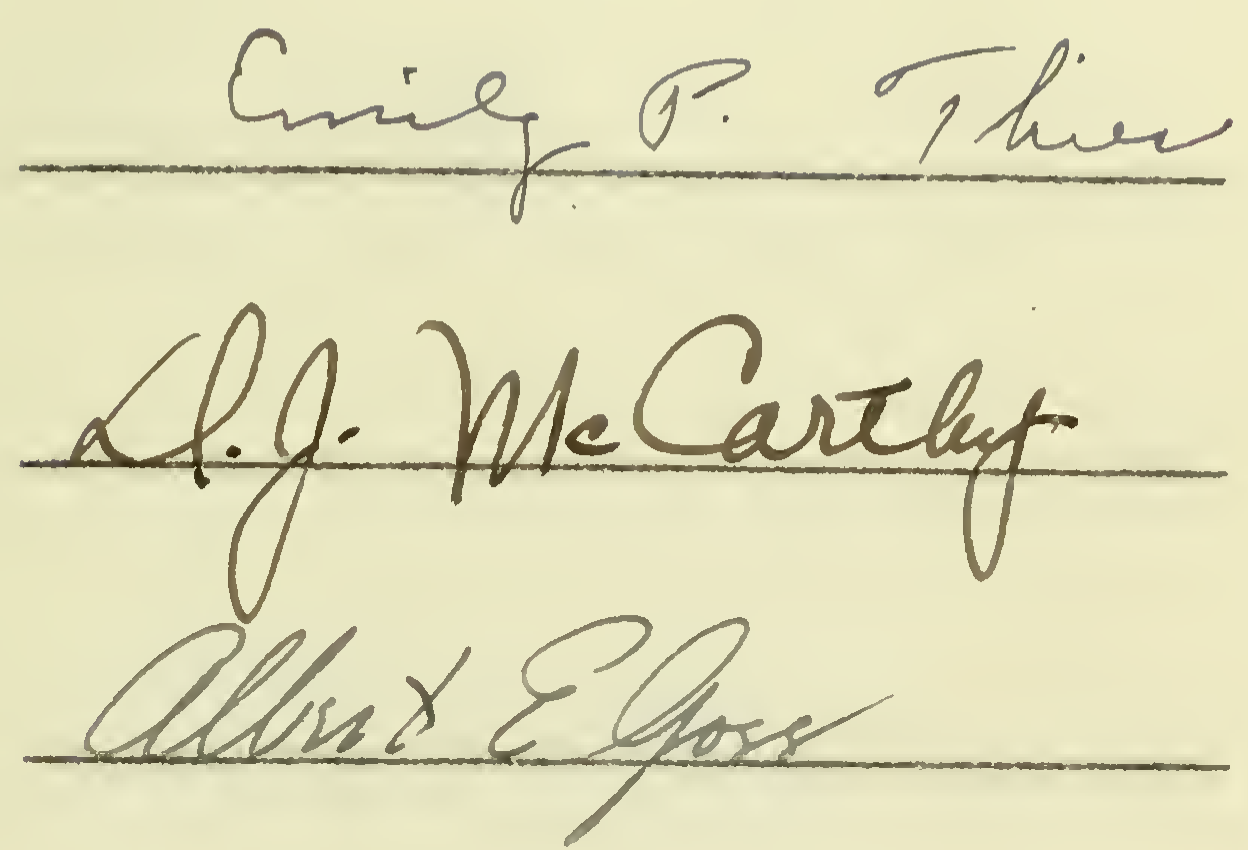
